\title{
The Role of Business Ethics in Improving the Quality of Job Performance
}

\author{
Aisha Abdalla Almahjob Jamal* \\ Department of Human Resources Management, College of Business, Al-Kamil University of Jeddah, Saudi Arabia
}

\begin{abstract}
Purpose: The study aims to identify the role of business ethics in improving the quality of job performance. Methods: A survey was carried out by recruiting 540 individuals, who were working with the Ministry of Youth and Sports of Republic of Sudan.

Results: The outcomes have been developed on the basis of three hypotheses. The reliability value of the questionnaire was 0.817 for the 18 variables. Majority of the respondents have shown positive or neutral responses towards the statements. The squared values of differential statements have shown idealistic outcomes in accordance with the work ethics.
\end{abstract}

Conclusion: It is concluded that it is necessary to develop the practice of work ethics, which will definitely result in increased quality of employees' performance.

Keywords: Business ethics; Job performance; Squared values; Honesty; Fairness

\section{Introduction}

Work ethics play a major role in the organizational success because it reflects the confidence of employees on their organization that will lead to the employees' development, transparency, integrity, organizational reputation, and better work processes. Work ethics is also significant in developing functional behavior in the public or private sector that received considerable attention [1-3]. The roots of functional behavior are already developed from the school's era. It develops a behavior among students that cheating in exams is not fair with self and others; therefore, strict dealing is required to perform the tasks. In such a way, the student gets used to respect the rights of others; for instance, waiting in line and abiding by the traffic rules. Such simple concepts must be taken seriously to develop the virtue of honesty and fairness as functional behavior that usually leads to work ethics $[4,5]$.

Career behaviors are generally known as principles, values, rules, and standards that are governed in the working environment. Work ethic in functional behaviors is also influenced by the factor of loyalty, discipline, productivity, and professionalism, good manners, collaboration with colleagues, public morality, and respect for clients. Moreover, maintaining business insights, following the rules and regulations, maintaining the property and funds, and the development of skills and abilities are also considered as common features of work ethics. The general function of ethics is the basics of behavior that plays a major role in influencing the job performance of employees [6-9]. It reflects the confidence of employees towards their organization along with the confidence of community. Therefore, the knowledge of ethics in public service and awareness of their role would be helpful to enhance their performance and reduce the burden. The study is significant to develop the role of business ethics in improving the quality of job performance $[8,10]$. Therefore, the study aims to identify the work ethics, learn about the business ethics and their impact on the behavior, identify the roles of business ethics in accordance with the organizational goals, and develop the recommendations, based on outcomes.

\section{Hypotheses of the Study}

$\mathbf{H}_{\mathbf{1}}$ : There is a direct relationship between lack of commitment towards work ethics and low quality of job performance among employees.
$\mathbf{H}_{2}$ : There is an association between patronage and low staff behavior.

$\mathbf{H}_{3}$ : There is a direct correlation between poor work ethics and low quality performance.

\section{Methodology}

The study has opted descriptive and analytical research design for attaining outcomes. A survey was carried out by recruiting 540 individuals, who were working with the Ministry of Youth and Sports of Republic of Sudan. Business ethics is defined as a set of principles and criteria, governing the behavior of individual (or group); these principles are helpful for determining about the right and wrong concepts in accordance with the scenario. SPSS version 20 has been opted for analyzing the collected data.

\section{Results and Discussion}

Cronbach's alpha test was used to measure the reliability and validity of questionnaire; the results are presented in Table 1 . The reliability value of the questionnaire is 0.817 for the 18 variables. Therefore, it can be said that the questionnaire was reliable and valid to be applied in research settings.

\section{Results of the First Hypothesis}

"There is a direct relationship between lack of commitment towards work ethics and low quality of job performance among employees."

\begin{tabular}{|c|c|c|}
\hline Self-honesty factor & Reliability factor & Number of variables \\
\hline 0.748 & 0.817 & 18 \\
\hline \multicolumn{3}{|c|}{ Table 1: Findings of Cronbach's alpha. } \\
\hline \multicolumn{3}{|c|}{}
\end{tabular}

*Corresponding author: Aisha Abdalla AlMahjob Jamal, Department of Human Resources Management, College of Business, Al-Kamil University of Jeddah, Saudi Arabia, Tel: 800-11-69528; E-mail: aishajamal82@yahoo.com

Recieved January 05, 2018; Accepted February 08, 2018; Published February 16,2018

Citation: Al Mahjob Jamal AA (2018) The Role of Business Ethics in Improving the Quality of Job Performance. J Entrepren Organiz Manag 7: 224. doi: 10.4172/2169026X.1000224

Copyright: ( 2018 Al Mahjob Jamal AA. This is an open-access article distributed under the terms of the Creative Commons Attribution License, which permits unrestricted use, distribution, and reproduction in any medium, provided the original author and source are credited. 
Table 2 shows the frequency distribution of the study sample, answering the statements of first hypothesis. To test statistically significant differences between the numbers of respondents, squared test was used to identify such differences.

Squared value has indicated the differences between sample preparation of first term (43.667), and this squared value is greater than the value of indexed at freedom (4) and abstract level (5\%). It indicated that the presence of statistically significant differences between respondent's answers is invalid as most of them have agreed to the statement.

Squared value further indicated the differences between the preparation of the study sample members to the second term (47.444); and this squared value is greater than the value of the indexed at freedom (4) and abstract level (5\%). It indicated the presence of statistically significant differences between respondents' answers and invalid neutrals.

Squared value also identified the differences between the preparations of the study sample members to the third term (17.000); this squared value was also greater than the value of indexed at freedom (4) and abstract level (5\%). It indicated the presence of statistically significant differences between respondents' answers and invalid neutrals. Squared value further mentioned the differences between the preparation of the study sample members to the second term (33.889) and this squared value was greater than the value of the indexed at freedom (4) and abstract level (5\%) at the sig value of 0.000 . It indicated the presence of statistically significant differences between respondents' answers and invalid neutrals that "Staff is committed to come on time as scheduled".

Squared value also showed the differences between the preparation of the study sample members to the second term (16.778); and this squared value is greater than the value of indexed at freedom (4) and abstract level (5\%). It indicated the presence of statistically significant differences between respondents' answers and invalid neutrals that Business insights are kept as secrets (Table 3). The business professionals are well-aware about the state of art techniques to analyze data, which has resulted in the dramatic improvement in data gathering [11]. Squared value of the last statement also identified the differences between the preparation of the study sample members (36.333); and this value squared is greater than the value of indexed at freedom (4) and abstract level (5\%). It indicated the presence of statistically significant differences between respondents' answers and invalid approver that "Employees take responsibility and show respect towards superiors and clients."

\section{Results of the Second Hypothesis}

"There is an association between patronage and low staff behavior."

Table 4 shows the frequency distribution of the study sample answering statements about second hypothesis. Table 5 summarizes the outcomes for the phrases for assessing statistically significant differences between the numbers of respondents to denote the differences (Tables 4 and 5).

Squared value indicated the differences between the sample preparation to first term (53.556), and this value is greater than the value of the indexed at freedom (4) and abstract level (5\%). It indicated the presence of statistically significant differences between respondents answers and invalid approver that there is no equal treatment between employees. Squared value further indicated the differences between the preparation of the study sample members to the second term (57.889) and this value squared is greater than the value of the indexed at freedom (4) and abstract level (5\%). It indicated the presence of statistically significant differences between respondents' answers and invalid approvers that there is no justice in the distribution of work between employees.

Squared value further identified the differences between the preparation of the study sample members to the second term (24.756) and this value squared is greater than the value of the indexed at freedom (4) and abstract level (5\%). It indicated the presence of statistically significant differences between respondents' answers and invalid neutrals that there is mediation while assigning new employees. Squared values have further shown the differences between the

\begin{tabular}{|c|c|c|c|c|c|}
\hline Statements & Strongly agree & Agree & Neutral & Disagree & Strongly Disagree \\
\hline Iterations & 28 & 144 & 104 & 184 & 80 \\
\hline Ancestry & $5.19 \%$ & $26.67 \%$ & $19.26 \%$ & $34.07 \%$ & $14.81 \%$ \\
\hline
\end{tabular}

Table 2: Frequency distribution.

\begin{tabular}{|c|c|c|c|c|c|c|c|}
\hline No. & Statement & $\begin{array}{l}\text { Degree of } \\
\text { Freedom }\end{array}$ & $\begin{array}{l}\text { Squared } \\
\text { Value }\end{array}$ & $\begin{array}{l}\text { Standard } \\
\text { Deviation }\end{array}$ & Mediator & $\begin{array}{l}\text { Significance } \\
\text { Value }\end{array}$ & Outcome \\
\hline 1. & $\begin{array}{l}\text { Care facility to the general appearance and behavior } \\
\text { and ethics }\end{array}$ & 4. & 43.667 & 1.15 & 4. & 0.000 & Agree \\
\hline 2. & $\begin{array}{l}\text { The staff is committed to rules and regulations and } \\
\text { work instructions }\end{array}$ & 4. & 47.444 & 1.06 & 3. & 0.000 & Neutral \\
\hline 3. & $\begin{array}{l}\text { The employee's loyalty to the organization is related } \\
\text { to improved performance. }\end{array}$ & 4. & 17.000 & 1.14 & 3. & 0.002 & Neutral \\
\hline 4. & Staff is committed to come on time as scheduled & 4. & 33.889 & 1.18 & 3. & 0.000 & Neutral \\
\hline 5. & Business insights are kept as secrets. & 4. & 16.778 & 1.15 & 3. & 0.002 & Neutral \\
\hline 6. & $\begin{array}{l}\text { Employees take responsibility and show respect } \\
\text { towards superiors and clients }\end{array}$ & 4. & 23.333 & 1.11 & 4. & 0.000 & Agree \\
\hline \multicolumn{2}{|c|}{ All phrases } & 4. & 132.15 & 1.15 & 3. & 0.000 & Neutral \\
\hline
\end{tabular}

Table 3: Statistically Significant Differences between the Numbers of Respondents.

\begin{tabular}{|c|c|c|c|c|c|}
\hline Statements & Strongly agree & Agree & Neutral & Disagree & Strongly Disagree \\
\hline Iterations & 20. & 92 & 78 & 181 & 169 \\
\hline Ancestry & $3.7 \%$ & $17.0 \%$ & $14.4 \%$ & $35.5 \%$ & $31.3 \%$ \\
\hline
\end{tabular}

Table 4: Frequency Distribution of the Study for $2^{\text {nd }}$ Hypothesis. 


\begin{tabular}{|c|c|c|c|c|c|c|c|}
\hline No. & Statement & $\begin{array}{l}\text { Degree of } \\
\text { Freedom }\end{array}$ & $\begin{array}{l}\text { Squared } \\
\text { Value }\end{array}$ & $\begin{array}{l}\text { Standard } \\
\text { Deviation }\end{array}$ & Mediator & $\begin{array}{l}\text { Significance } \\
\text { Value }\end{array}$ & Outcome \\
\hline 1. & There is no equal treatment between employees & 4. & 53.556 & 1.08 & 4. & 0.000 & Agree \\
\hline 2. & $\begin{array}{l}\text { There is no justice in the distribution of work } \\
\text { between employees }\end{array}$ & 4. & 57.889 & 1.09 & 4. & 0.000 & Agree \\
\hline 3. & $\begin{array}{l}\text { There is a mediation when assigning new } \\
\text { employees }\end{array}$ & 4. & 24.756 & 1.03 & 3. & 0.000 & Neutral \\
\hline 4. & No initiatives are taken for established objectives & 4. & 30.222 & 1.17 & 4. & 0.000 & Agree \\
\hline 5. & $\begin{array}{l}\text { They do not listen the opinions of heads and staff for } \\
\text { development work }\end{array}$ & 4. & 15.000 & 1.25 & 4. & 0.005 & Agree \\
\hline 6. & $\begin{array}{l}\text { There are tradeoffs in delivering services from } \\
\text { another agent. }\end{array}$ & 4. & 36.111 & 1.10 & 4. & 0.000 & Agree \\
\hline \multicolumn{2}{|c|}{ All phrases } & 4. & 166.20 & 1.18 & 4. & 0.000 & Agree \\
\hline
\end{tabular}

Table 5: Statistically Significant Differences between the Numbers of Respondents.

\begin{tabular}{|c|c|c|c|c|c|}
\hline Statements & Strongly agree & Agree & Neutral & Disagree & Strongly Disagree \\
\hline Iterations & 26 & 84 & 62 & 209 & 159 \\
\hline Ancestry & $4.8 \%$ & $15.6 \%$ & $11.5 \%$ & $38.7 \%$ & $29.4 \%$ \\
\hline
\end{tabular}

Table 6: Frequency Distribution of Study Sample.

\begin{tabular}{|c|c|c|c|c|c|c|c|}
\hline No. & Statement & $\begin{array}{l}\text { Degree of } \\
\text { Freedom }\end{array}$ & $\begin{array}{l}\text { Squared } \\
\text { Value }\end{array}$ & $\begin{array}{l}\text { Standard } \\
\text { Deviation }\end{array}$ & Mediator & $\begin{array}{l}\text { Significance } \\
\text { Value }\end{array}$ & Outcome \\
\hline 1. & Exploit employees work time to do other things. & 4. & 31.889 & 1.20 & 4. & 0.000 & Agree \\
\hline 2. & $\begin{array}{l}\text { There is a lack of commitment of employees to } \\
\text { perform work on time }\end{array}$ & 4. & 35.333 & 1.14 & 4. & 0.000 & Agree \\
\hline 3. & May be out of work without permission or excuse & 4. & 35.333 & 1.27 & 4. & 0.000 & Agree \\
\hline 4. & $\begin{array}{l}\text { In task allocation, compatibility is not taken } \\
\text { into account between the nature of job and the } \\
\text { employee's abilities }\end{array}$ & 4. & 33.889 & 1.05 & 4. & 0.000 & Agree \\
\hline 5. & Care facility to the amount of work done more than quality & 4. & 51.111 & 1.14 & 4. & 0.000 & Agree \\
\hline 6. & $\begin{array}{l}\text { Development staff cares only for professional } \\
\text { advancement }\end{array}$ & 4. & 24.111 & 1.26 & 4. & 0.000 & Agree \\
\hline \multicolumn{2}{|c|}{ All phrases } & 4. & 205.72 & 1.18 & 4. & 0.000 & Agree \\
\hline
\end{tabular}

Table 7: Statistically Significant Differences between the Numbers of Respondents.

preparation of the study sample members to the second term (30.222) and this value squared is greater than the value of the indexed at freedom (4) and abstract level (5\%). The study has shown the presence of statistically significant differences between respondents' answers and invalid approvers that no initiatives are taken for established objectives. Squared value also identified the differences between the preparation of the study sample members to the second term (15.000) and this value squared is greater than the value of the indexed at freedom (4) and abstract level (5\%). The findings identified statistically significant differences between respondents' answers and invalid approvers that they do not listen the opinions of heads and staff for development work.

Squared value also mentioned the differences between the preparation of the study sample members to the second term (36.111) and this value squared is greater than the value of the indexed at freedom (4) and abstract level (5\%). The study indicated the presence of statistically significant differences between respondents' answers and invalid approvers that there are tradeoffs in client service delivery.

\section{Results of Third Hypothesis}

"There is a direct correlation between poor work ethics and low quality performance."

Table 6 shows the frequency distribution of study sample, answering the statements of third hypothesis. Table 7 has shown statistically significant differences between the numbers of respondents' squared values for denoting the differences (Tables 6 and 7).

Squared value has identified the differences between the sample preparation to the first term (31.889), and this squared value is greater than the value of freedom index (4) and abstract level (5\%). It indicated the presence of statistically significant differences between respondents' answers and invalid approver that exploit employees work time to do other things. Squared value have also identified the differences between the preparation of the study sample members to the second term (35.333) and this value squared is greater than the value of the indexed at freedom (4) and abstract level (5\%). It indicated the presence of statistically significant differences between respondents' answers and invalid approvers that there is a lack of commitment of employees to perform work on time.

Squared value also showed the differences between the preparation of the study sample members to the second term (35.333) and this value squared is greater than the value of the indexed at freedom (4) and abstract level (5\%). It indicated the presence of statistically significant differences between respondents' answers and invalid approvers that "may be out of work without permission or excuse". Squared value has shown the differences between the preparation of the study sample members to the second term (51.111) and this value squared is greater than the value of the indexed at freedom (4) and abstract level (5\%). It indicated the presence of statistically significant differences between respondents' answers and invalid conformists "in task allocation, compatibility is not taken into account between the nature of job and the employee's abilities".

Squared value has further identified the differences between the preparation of the study sample members to the second term (52.556), 
Citation: AIMahjob Jamal AA (2018) The Role of Business Ethics in Improving the Quality of Job Performance. J Entrepren Organiz Manag 7: 224. doi: 10.4172/2169-026X.1000224

Page 4 of 4

and this value squared is greater than the value of the indexed at freedom (4) and abstract level (5\%). The study has indicated the presence of statistically significant differences between respondents' answers and invalid approvers "care facility to the amount of work done more than quality". Squared value has shown the differences between the preparation of study sample members to second term (24.111), and this value squared is greater than the value of the indexed at freedom (4) and abstract level (5\%). It indicated the presence of statistically significant differences between respondents' answers and invalid approvers' development staff cares only for professional advancement. The professionals are likely to use these findings to address barriers, which prevent them from participating in different advanced procedures [12].

\section{Conclusion}

There are different types of foundations and ethical standards of public service within the organizational settings. Therefore, it is necessary to develop the practices of work ethics, which will definitely result in the increased quality of employees' performance. For this purpose, staff training is required periodically on the tasks and responsibilities. Moreover, awareness of social responsibility and ethical dimensions will also place a positive impact on the performance improvement. There is also a need to develop effective programs for reducing medium and administrative corruption that outrageous the motivation of employees related to work ethics.

\section{Acknowledgement}

The author is very thankful to all the associated personnel in any reference that contributed in/for the purpose of this research.

\section{References}

1. Goetsch DL, Davis SB (2014) Quality management for organizational excellence. Upper Saddle River, NJ: pearson.
2. Marta JKM, Singhapakdi A, Lee DJ, Sirgy MJ, Koonmee K, et al. (2013) Perceptions about ethics institutionalization and quality of work life: Thai versus American marketing managers. Journal of Business Research 66: 381-389.

3. Parrott $L$ (2014) Values and ethics in social work practice. Learning Matters.

4. Murtaza G, Abbas M, Raja U, Roques O, Khalid A, et al. (2016) Impact of Islamic work ethics on organizational citizenship behaviors and knowledgesharing behaviors. Journal of Business Ethics 133: 325-333.

5. Banks S (2014) Reclaiming social work ethics: Challenging the new public management. Ethics, critical and radical debates in social work 1: 1-24.

6. Zhang M, Di Fan D, Zhu CJ (2014) High-performance work systems, corporate social performance and employee outcomes: Exploring the missing links. Journal of Business Ethics 120: 423-435.

7. Fan D, Cui L, Zhang MM, Zhu CJ, Hartel CE, et al. (2014) Influence of high performance work systems on employee subjective well-being and job burnout: empirical evidence from the Chinese healthcare sector. The International Journal of Human Resource Management 25: 931-950.

8. Carter MZ, Armenakis AA, Feild HS, Mossholder KW (2013) Transformationa leadership, relationship quality, and employee performance during continuous incremental organizational change. Journal of Organizational Behavior 34 942-958.

9. Mulki JP, Caemmerer B, Heggde GS (2015) Leadership style, salesperson's work effort and job performance: the influence of power distance. Journal of Personal Selling \& Sales Management 35: 3-22.

10. Bouckenooghe D, Zafar A, Raja U (2015) How ethical leadership shapes employees' job performance: The mediating roles of goal congruence and psychological capital. Journal of Business Ethics 129: 251-264.

11. Fleisher CS, Bensoussan BE (2015) Business and competitive analysis: effective application of new and classic methods. FT Press.

12. Chongthammakun $R$ (2013) ICT Development and Organizational Change in the Thai Public Sector. 